\title{
Rahim Mandul Allah: Suatu Konstruksi Imajinatif yang Menginterpretasi Realitas Chaotic Penciptaan bagi Pengalaman Perempuan Mandul
}

\author{
Risye Yulika Rieuwpassa \\ Sekolah Tinggi Filsafat Theologi Jakarta \\ risyefussy@gmail.com
}

\section{D01: https://doi.org/10.34307/b.v4i2.304}

\begin{abstract}
This paper proposes a constructive imagination that sees the world as an infertile womb of God in the context of creation. The chaosmic dimension of Catherine Keller gives positive fluctuations for nihil and chaos that is often interpreted as evil and ugliness. My thesis is that the chaosmic contributes to the imagination's positive affirmation of infertility and God's infertility. This paper attended purpose to give a new lens to the reality of Barren women and make approving for barren women in the social community. The method was a descriptive qualitative method with a literary study approach. Finally, this paper invites the reader to accept barren and childfree women and see the world as a home and house in a diversity of chaotic.
\end{abstract}

Keywords: infertility, the infertile womb of God, Chaotic, Barren Woman

\begin{abstract}
Abstrak: Tulisan ini mengusulkan sebuah imajinasi konstruktif yang melihat dunia sebagai rahim mandul Allah dalam konteks penciptaan. Dimensi chaosmic dari Catherine Keller menghasilkan fluktuasi positif bagi nihil dan chaos yang sering ditafsir sebagai kejahatan dan keburukan. Penulis berpendapat bahwa Pemikiran tersebut turut memberi ruang imajinasi untuk mengafirmasi kemandulan secara positif dan menampilkan kemandulan Allah. Penulisan ini bertujuan untuk memberi lensa baru dalam melihat realitas kemandulan perempuan, serta memberi ruang bagi perempuan mandul dalam komunitas masyarakat. Metode yang digunakan adalah metode deskriptif, kualitatif deskriptif, dengan pendekatan studi literatur. Pada akhirnya, Konstruksi dalam tulisan ini menghasilkan undangan bagi pembaca untuk menerima perempuan mandul dan perempuan yang memutuskan untuk tidak memiliki anak. Serta, melihat dunia sebagai rumah bersama dalam kebersamaan chaotic.
\end{abstract}

Kata Kunci: Rahim Mandul Allah, Chaotic, Chaordic, Perempuan Mandul

$\begin{array}{llll}\text { Article History : } & \text { Received: 10-08-2021 } & \text { Revised: 15-12-2021 Accepted: 16-12-2021 }\end{array}$

\section{Pendahuluan}

Rahim dan tubuh perempuan merupakan dua hal yang tidak bisa dipisahkan. Seorang perempuan diciptakan istimewa karena ia memiliki rahim. Rahim pada tubuh perempuan membuat perempuan berbeda dengan laki-laki, baik fisik maupun gender. Sejauh ini, percakapan teologi Kristen tentang tubuh perempuan selalu dikaitkan dengan status dan 
kedudukan perempuan dalam masyarakat, sedangkan, teologi rahim hampir tidak pernah terdengar dalam percakapan teologi.

Percakapan mengenai teologi rahim berkaitan dengan teologi penciptaan. Allah digambarkan sebagai Pencipta yang menciptakan segala sesuatu dalam rahim-Nya dan senantiasa merahimi ${ }^{1}$ ciptaan dengan kasih tak berkesudahan. Christian Siregar, dengan mengutip Sallie McFague, berpendapat bahwa Allah digambarkan sebagai ibu yang mengandung alam semesta dalam rahim-Nya. Allah mengandung, melahirkan, menyusui, dan merawat anak-anak-Nya. ${ }^{2}$

Selain itu, teologi rahim juga turut mempercakapkan proses penciptaan melalui rahim seorang perempuan. Perempuan melalui pengalaman reproduksi, yakni mengandung, melahirkan, dan menyusui menciptakan kehidupan bersama Allah. Christy Bauman seorang womanis dan psikoterapis berpendapat bahwa setiap perempuan diundang untuk menciptakan kehidupan bersama Allah. Baik kehidupan rohani, emosi, maupun jasmani, sama-sama menggunakan siklus yang dapat dipakai dalam proses penciptaan bersama Allah. Siklus tersebut adalah siklus menstruasi yang hanya dimiliki oleh perempuan. ${ }^{3}$

Pemahaman rahim yang demikian kontras dengan pengalaman-pengalaman perempuan mandul. Keterbatasan dan ketidakmampuan seorang perempuan untuk bereproduksi menyebabkan stigma melekat pada tubuh mereka. Lisa Powell menegaskan bahwa, meskipun kemandulan merupakan kondisi medis, faktor-faktor sosial dan budaya secara signifikan dapat mempengaruhi pengalaman perempuan terhadap kemandulan. ${ }^{4}$ Peran ibu hampir identik dengan feminin, sehingga perempuan mandul dianggap tidak memiliki unsur sentral dari identitas gender mereka. ${ }^{5}$ Perempuan mandul sering dipandang rendah dan dianggap tidak mampu memenuhi standar normatif seorang perempuan, yakni mengandung dan melahirkan. Hal ini menimbulkan trauma dan mempengaruhi pengalaman perempuan ${ }^{6}$ di tengah komunitas masyarakat. Bukan hanya itu, perempuan-perempuan yang memutuskan untuk tidak memiliki anak pun kerap mendapat perlakuan serupa.

Janice De-Whyte berpendapat bahwa kemandulan berkaitan dengan kehormatan yang diberikan kepada seseorang. De-Whyte menjelaskan, di Israel memiliki banyak anak

\footnotetext{
${ }^{1}$ Kata teologis lain untuk kata merahimi adalah "merengkuh, memeluk, mendekap"

${ }^{2}$ Christian Siregar, "Menyoal Jenis Kelamin Allah Dalam Perspektif Teologi Feminis: Menuju Teologi Yang Lebih Berkeadilan Terhadap Perempuan," Humaniora (2015): 433-443.

${ }^{3}$ Christy Angelle Bauman, Theology of The Womb: Knowing God through the Body of a Woman (Eugene: Wipf and Stock, 2019), 119-121.

4 Lisa Powell, "The Infertile Womb of God: Ableism in Feminist Doctrine of God," CrossCurrents 65, no. 1 (2015): 116-138.

${ }^{5}$ Larissa Remennick, "Childless in the Land of Imperative Motherhood: Stigma and Coping Among Infertile Israeli Women," Sex roles 43, no. 11 (2000): 822.

${ }^{6}$ Megan Clay, "Abundant Body Narratives: Re-Visioning the Theological Embodiment of Women through Feminist Theology and Art as a Way of Flourishing," Feminist Theology 25, no. 3 (2017): 249.
} 
merupakan sebuah kehormatan, sedangkan kemandulan dilihat sebagai cobaan atau hukuman Allah.7 Alkitab menarasikan kemandulan adalah aib, keburukan, dan sering ditolak. Namun, kisah perempuan mandul dalam Alkitab selalu berakhir menggembirakan. Tak sedikit diantara mereka yang rahimnya diberkati dan mengandung, sekalipun diusia yang tidak lagi produkstif secara biologis. ${ }^{8}$ Yohanes Krismatyo Susanta menjelaskan bahwa, akhir yang bahagia dari pengalaman perempuanperempuan mandul tersebut bukanlah inti dari kisah-kisah tersebut, melainkan wujud kasih setia dan belas kasih Allah kepada umat-Nya, serta intervensi Allah bagi kehidupan keluarga. Akan tetapi, kisah-kisah tersebut tidak dapat dipandang secara normatif untuk diterapkan pada konteks masa kini. ${ }^{9}$

Kisah-kisah dimaksud telah dibahas dalam beberapa karya teologis, misalnya, dalam tulisan-tulisan, Yohanes Krismatyo Susanta, Yenny Anita Pattinama and Febriaman Lalaziduhu Harefa, serta disertasi dari David Schones. Menggunakan pendekatan dan interpretasi yang berbeda, tulisan-tulisan tersebut mengargumentasikan pengalaman mandul yang dialami Sara, Hana, dan Elisabeth sebagai berkat dan kehendak atau kuasa Allah dalam kehidupan manusia, khususnya atas rahim perempuan. ${ }^{10}$ Allah turut bekerja dalam proses penciptaan kehidupan baru dalam rahim perempuan. ${ }^{11}$ Rancangan Allah atas kemandulan yang dialami oleh Sara, Hana, Elisabeth, serta perempuan-perempuan mandul lainnya terselip rancangan besar Allah atas sejarah bangsa Israel. Mengutip Walter Brueggemann, Schones menulis, Kemandulan Hana tidak disebabkan oleh dosa, sebaliknya merupakan lambang yang menggambarkan kerajaan israel. Ketidakberdayaan Hana adalah alat yang secara efektif menunjukkan rencana ilahi Allah. ${ }^{12}$ Pattinama dan Herafa meyakini bahwa kisah Hana menampilkan spiritualitas seorang perempuan, yang dalam situasi sulit tetap setia dan bergantung pada Allah, menjaga kekudusan hidup dan konsisten dalam menepati janji. ${ }^{13}$

${ }^{7}$ Janice Pearl Ewurama De-Whyte, Wom(b)an: A Cultural-Narrative Reading of the Hebrew Bible Barrenness Narratives (Leiden: Brill, 2018), 3.

${ }^{8}$ Cerita-cerita tersebut dapat ditemui dalam teks Kejadian 21:1-7; 25:19-26; 29:31-30:24, Hakimhakim 13:1-24, 1 Samuel 1, dan Lukas 1:7-13

9 Yohanes Krismantyo Susanta, "Teologi Biblika Kontekstual Di Seputar Persoalan Perempuan, Keturunan, Dan Kemandulan," Religious: Jurnal Studi Agama-Agama dan Lintas Budaya 4, no. 3 (April 4, 2020): 187, https://journal.uinsgd.ac.id/index.php/Religious/article/view/8079.

${ }^{10}$ Ibid., 186; Yenny Anita Pattinama and Febriaman Lalaziduhu Harefa, "Spiritualitas Hana Menurut 1 Samuel 1: 1-28 Dan Implementasinya Bagi Wanita," SCRIPTA: Jurnal Teologi dan Pelayanan Kontekstual 10, no. 2 (2020): 7; David A. Schones, "Infertility in 1 Samuel 1: Toward a Hermeneutic of Reproduction" (Southern Methodist University, 2019), 34.

11 Susanta, "Teologi Biblika Kontekstual Di Seputar Persoalan Perempuan, Keturunan, Dan Kemandulan," 187; Pattinama and Harefa, "Spiritualitas Hana Menurut 1 Samuel 1: 1-28 Dan Implementasinya Bagi Wanita," 7.

${ }^{12}$ Schones, "Infertility in 1 Samuel 1: Toward a Hermeneutic of Reproduction," 34. Wanita," 17.

${ }^{13}$ Pattinama and Harefa, "Spiritualitas Hana Menurut 1 Samuel 1: 1-28 Dan Implementasinya Bagi 
Berbeda dengan penelitian-penelitian tersebut diatas, penulisan ini bertujuan untuk memberikan lensa baru bagi kemandulan sekaligus memberi ruang bagi perempuan-perempuan mandul, perempuan yang terlahir tanpa rahim, yang rahimnya telah diangkat, dan mengalami kemandulan total, serta memberi ruang bagi hak-hak kebebasan reproduksi perempuan. Penulisan ini tidak akan diarahkan untuk menafsir atau meninjau secara biblis pengalaman-pengalaman perempuan mandul dalam Alkitab.

Pembahasan dimaksud akan dilakukan dengan menggunakan metafora rahim mandul Allah. ${ }^{14}$ Tafsir dekonstruktif dari Catherine Keller yang menawarkan dimensi chaosmic penciptaan dunia menolong penulis untuk memahami dinamika chaosmos yang memicu lahirnya metafora rahim mandul Allah. Penulis berargumen bahwa fluktuasi positif dari dinamika Chaosmic Catherine Keller memberi ruang imajinatif untuk mengafirmasi kemandulan secara positif, dan menampilkan kemandulan Allah.

Dengan demikian, tulisan ini menawarkan sebuah imajinasi konstruktif yang mendalami rahim mandul Allah. Untuk itu, tulisan ini akan terfokus pada dua hal, pertama, membahas dinamika chaosmos penciptaan sebagai wajah kemandulan Allah. Kedua, menjadikan metafora rahim mandul Allah sebagai ruang atau tempat bagi keberagaman pengalaman tubuh perempuan, khususnya mengenai pengalaman perempuan mandul.

\section{Metode Penelitian}

Proses konstruksi dalam penulisan ini menggunakan metode kualitatif deskriptif, dengan pendekatan studi pustaka dan imajinatif. Metode deskriptif menekankan pada kalimat rinci, lengkap, dan mendalam guna mendukung penyajian data. ${ }^{15}$ Metode deskriptif umumnya dipakai untuk menguraikan informasi mengenai permasalahan yang sedang diteliti. ${ }^{16}$ Mengandalkan daya pikir imajinatif dan didukung oleh literatur yang sesuai dengan topik pembahasan, penulis akan mendekripsikan dan menggambarkan tema kemandulan secara metaforis bagi Allah dalam kaitannya dengan teologi penciptaan.

14 Penelitian teologis tentang rahim mandul Allah sudah pernah dipercakapkan oleh Lisa Powell dalam artikel berjudul "The Infertile Womb of God: Ableisme in Feminis Doctrine of God". Di dalam karya tersebut Powell mengkritisi teologi feminis yang kerap memuliakan kesuburan dan membangun doktrin tentang Allah dalam gagasan-gagasan yang secara normatif disesuaikan dengan kapasitas fisiologi perempuan untuk melahirkan anak, sehingga meniadakan dan mengabaikan keberadaan perempuan mandul. Gambaran tentang Allah sebagai ibu, bagi Powell, mengonfirmasi kembali doktrin Kristen tentang penciptaan sebagai tindakan Ilahi Allah, sehingga Allah dianggap memiliki rahim yang melahirkan dan memelihara ciptaan, bagaikan seorang ibu. Powell menegaskan bahwa, Gambaran Allah yang subur disusun berdasarkan anggapan fisiologi perempuan secara menyeluruh, meneguhkan segala sesuatu yang dianggap normal bagi tubuh perempuan, ini menimbulkan stigma pada diri perempuan Mandul. Powell mengusulkan gambaran Allah yang mandul sebagai gambar disabilitas Allah. Powell berharap gambaran dan metafora perempuan untuk Allah tidak hanya mempertimbangkan idealisme ibu mengandung, melainkan menjadi cara kita untuk menghadirkan berbagai bahasa dan pemikiran mengenai rahim itu sendiri. Powell, "The Infertile Womb of God: Ableism in Feminist Doctrine of God."

15 Farida Nugrahani, Metode Penelitian Kualitatif, Solo: Cakra Books, 2014, 96.

16 Sonny Eli Zaluchu, "Strategi Penelitian Kualitatif Dan Kuantitatif Di Dalam Penelitian Agama," Evangelikal: Jurnal Teologi Injili dan Pembinaan Warga Jemaat 4, no. 1 (2020): 33. 
Penulisan ini memanfaatkan secara mendalam tulisan dari Catherine Keller, Face of the Deep: A Theology of Becoming untuk mengonstruksi metafora rahim mandul Allah. Sederhananya, teologi Chaosmos dari Keller akan dipakai untuk mengimajinasi penciptaan dari chaos sebagai wajah kemandulan Allah, sekaligus mereinterpreasi dinamika chaosmic penciptaan. Selain itu, penulis juga akan menggunakan literatur lain untuk mendeskripsikan imajinasi kemandulan Allah dan implikasinya bagi pengalaman perempuan mandul.

Adapun sistematika penulisan sebagai berikut; bagian pertama menampilkan model panenteisme sebagai bagian dari realitas penciptaan dunia yang juga memperlihatkan feminitas Allah melalui metafora dunia sebagai rahim Allah. Bagian ini penting dikaji diawal karena akan menjadi landasan untuk memahami metafora rahim mandul Allah. Bagian kedua berisi imajinasi konstruktif tentang penciptaan dari chaos. Dekonstruksi pikir dari Catherine Keller akan disajikan pada bagian ini untuk mengimaji kemandulan Allah. Pada akhirnya, bagian ketiga berisi kajian penulis terkait keberadaan dan penerimaan perempuan mandul dalam semesta yang chaotic.

\section{Hasil dan Pembahasan}

\section{Panenteisme Berspektif Rahim Allah}

Dewasa ini, kajian dan pendekatan yang dipakai untuk menjelaskan dinamika dan problematika penciptaan dunia berdasarkan Iman Kristen cukup beragam. Salah model yang dipakai adalah model Panenteisme. Panenteisme menyoroti isu-isu evolusioner dan teologi mengenai asal-usul dan/atau kemunculan dunia. Secara literal, panenteisme berarti "semua di dalam Allah" atau dengan kata lain "dunia berada di dalam Allah".17 Bagi Philip Clayton etimologi tersebut agak menyesatkan sebab kata in/en berarti ambigu, yakni "semua di dalam Allah" dan "Allah di dalam semua."18 Ambiguitas tersebut memberi sudut pandang baru bagi teologi rahim, yakni dunia sebagai rahim Allah dalam konteks penciptaan, yang mengabstraksi relasi intim antara Allah dan dunia ciptaan. Dengan kata lain, para panenteis berupaya untuk menyeimbangkan transendensi dan imanensi Allah, sekaligus mengklaim keintiman hubungan antara Allah dan dunia ciptaan. ${ }^{19}$

Benedikt Paul Göcke seorang filsuf dan teolog asal Jerman menginterpretasi panenteisme dengan mengatakan bahwa dunia adalah bagian (milik) intrinsik Allah.

17 Philip Clayton, "Panentheisms East and West," Sophia 49, no. 2 (2010): 183-191; Purushottama Bilimoria and Ellen Stansell, "Suturing the Body Corporate (Divine and Human) in the Brahmanic Traditions," in Sophia, 2010, 237-259.

18 Clayton, "Panentheisms East and West," 184.

19 David Griffin, "Panentheism: A Postmodern Revelation," in In Whom We Live and Move and Have Our Being: Panentheistic Reflections on God's Presence in a Scientific World, ed. Philip Clayton and Arthur Robert Peacocke (Grand Rapids, MI: William B. Eerdmans Pub., 2004), 39. 
Menurutnya, panenteisme bukan alternatif yang menarik bagi teisme klasik, ${ }^{20}$ sebaliknya keduanya mencerminkan spasialitas relasi antara Allah dan dunia ciptaan. Penggunaan kata In/en mengklarifikasi ketidakjelasan teisme klasik dan panteisme yang menyatakan bahwa segala suatu berada di luar Allah atau bahwa Allah identik dengan (jumlah) segala sesuatu. Göcke menulis,

That is, God and world are conceived as occupying different, spatial locations, with one being inside the other.' 5 Although it is true that most prepositions like 'in' or 'outside of' have a spatial connotation when they are used as expressions of a natural language, it is wrong to suppose that we are committed to a spatial interpretation of these prepositions....21 Instead, we are free to define these prepositions as technical terms of a philosophical language. ${ }^{22}$

Bagi Göcke kata In/en pada panenteisme bukanlah suatu masalah spesifik, melainkan ungkapan yang menyatakan hubungan antara Allah dan dunia ciptaan, bahwa Allah dan dunia dipahami "saling menempati". Clayton memperjelas hal ini dengan menuliskan, Ambiguitas in/en memposisikan hubungan antara dunia dan sumber utama, antara Allah dan dunia, dan antara yang tak terbatas dan semua yang terbatas. ${ }^{23}$ Akan tetapi, para panenteis tidak menegaskan bahwa Allah mahakuasa dan menolak untuk memperlakukan realitas yang tidak manusiawi. Mereka sepakat bahwa dalam panenteisme, transenden dalam immanen dan immanen di dalam transenden tersebut. ${ }^{24}$

Harald Atmanspacher and Hartmut von Sass berpendapat bahwa hubungan antara Allah dan dunia ciptaan adalah hubungan internal, yang berarti berbeda dengan eksternal. ${ }^{25}$ Terkait itu, Niels Henrik Gregersen menegaskan bahwa panenteisme berarti dunia bukan hanya dalam diri Allah, tetapi juga merupakan bentuk respons dunia kepada Allah. ${ }^{26}$ Secara konstruktif, panenteisme menggarisbawahi realitas penciptaan Allah di dunia dan pengaruh dunia atas Allah. Atmanspacher dan von Sass meyakini bahwa tema umum dari berbagai wajah panenteisme adalah kehadiran Allah di dunia dan keunikan karakteristik Allah dan dunia. Namun, berbagai bentuk panenteisme berkaitan dengan sifat konkret dari relasi intim antara Allah dan bukan Allah dalam berbagai pendekatan. ${ }^{27}$

Percakapan lebih lanjut mengenai panenteisme dalam kaitannya dengan proses penciptaan dunia turut memperlihatkan usaha untuk menampilkan feminitas Allah.

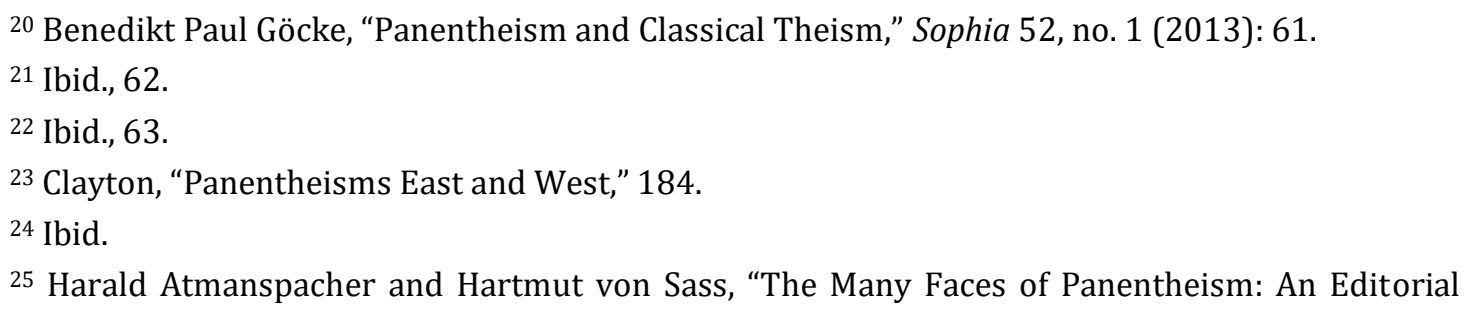
Introduction," Zygon (2017): 1031.

26 Neils Henrik Gregersen, "Three Varieties of Panentheism," in In Whom We Live and Move and Have Our Being: Panentheistic Reflections on God's Presence in a Scientific World, ed. Philip Clayton and Arthur Robert Peacocke (Grand Rapids, MI: William B. Eerdmans Pub., 2004), 19.

27 Atmanspacher and von Sass, “The Many Faces of Panentheism: An Editorial Introduction," 1031. 
Sejumlah metafora feminin digunakan untuk menegaskan hubungan antara Allah dan dunia ciptaan. Arthur Peacocke dan Sallie McFague, misalnya, dengan menggunakan pendekatan yang cukup berbeda, keduanya mengusulkan model prokreasi untuk menyatakan gagasan dunia sebagai tubuh Allah, dan memperkuat keyakinan panenteistik terhadap relasi intim antara Allah dan dunia ciptaan. Bagi McFague, model prokreasi menegaskan dunia berasal dari Allah, bukan "dari ketiadaan" atau materi lain selain Allah. Menanggapi creatio ex nihilo, McFague mengusulkan creation out of God, dan mengklaim bahwa segala sesuatu berada di dalam dan dari Allah, tetapi tidak berarti Allah identik dengan ciptaan. ${ }^{28}$ Hal ini menggambarkan kehidupan yang bergerak dan memiliki keberadaan di dalam Allah, tetapi tidak sebaliknya. McFague memperjelas argumennya dengan menggunakan metafora ibu yang sedang mengandung realitas dalam rahimnya dan melalui tubuhnya kehidupan tercipta atau terbentuk. ${ }^{29}$

Sedangkan, Peacocke menggunakan istilah panentheistic-procreative. Di dalam tulisan berjudul Midwifery as a Model for Ecological Ethics: Expanding Arthur Peacocke's Models of "Man-in-Creation,"30 Gloria L. Schaab menjelaskan bahwa, menurut Peacocke gambaran tentang Allah dalam teisme klasik mencerminkan imajinasi patriarki dan menggambarkan Allah berada di luar dunia. Peacocke membayangkan keintiman, interfensi, dan interpretasi dalam proses penciptaan sebagai bahasa prokreasi, yang menawarkan sarana untuk berbicara tentang Allah sebagai Pencipta. ${ }^{31}$ Secara eksplisit, Peacocke menggunakan metafora rahim. Baginya, Allah mencipta dalam diri-Nya sendiri, layaknya embrio yang berdiam di dalam rahim seorang perempuan. ${ }^{32}$ Peacocke menulis,

However, in keeping with a female panentheistic-procreative model of God as Trinity, I now propose an additional model of humanity's role - the model of the midwife in the process of procreation. In this model, God is conceived as transcendent Mother, birthing the incarnate cosmos through the immanent creativity of the cosmos itself. The emphasis in this model is on natural processes and interdependence... Those who exercise the role of professional midwife embrace a variety of values education and expertise, vigilance and attentiveness, nurturance and gentleness, sensitivity and respect toward the persons and processes involved in the emergence of new life. 33

Tawaran McFague dan Peacocke menunjukkan bahwa pengintegrasian model prokreativitas perempuan dan panenteisme menghasilkan suatu model kolektif untuk

${ }^{28}$ Sallie McFague, The Body of God: An Ecological Theology (Minneapolis: Fortress Press, 1993), Kindle; Loc. 2077.

29 Ibid.

30 Gloria L. Schaab, "Midwifery as a Model for Ecological Ethics: Expanding Arthur Peacocke's Models of 'Man-in-Creation,'” Zygon 42, no. 2 (2007): 488.

31 Ibid., 489-490.

${ }^{32}$ Catherine Keller, The Face of the Deep: A Theology of Becoming (Florence: Routledge, 2003), 191.

${ }^{33}$ Schaab, "Midwifery as a Model for Ecological Ethics: Expanding Arthur Peacocke's Models of 'Man-in-Creation,"' 491. 
kreativitas evolusi dalam konteks penciptaan dunia. Selain itu, model prokreasi melindungi identitas Allah yang berbeda dengan dunia dan mencerminkan ketergantungan mutlak ciptaan kepada Allah. Oleh karenanya, panenteisme memberi ruang bagi teologi rahim untuk menyatakan gagasan dunia sebagai rahim Allah, bahwa Allah seakan-akan memiliki tubuh dan rahim, dan merahimi semesta dalam rahim-Nya. Sederhananya, wajah lain dari panenteisme menggambarkan Allah yang merengkuh segenap ciptaan dalam rahim-Nya dan berdiam bersama seluruh ciptaan. Relasi antara Allah dan ciptaan pun digambarkan sebagai relasi tak terpisahkan dan relasi dengan kasih tak terbatas, layaknya hubungan antara seorang ibu dan anak dalam kandungan, yang terhubung lewat tali pusar. ${ }^{34}$

Dengan demikian, dunia sebagai rahim Allah merupakan tempat bagi kuasa kreatif Allah untuk menciptakan segala sesuatu. Artinya, Allah bekerja dan bertindak produktif dalam menghasilkan segala sesuatu. Hubungan antara Allah dan ciptaan pada dasarnya merupakan hubungan teologis yang mencerminkan relasi timbal-balik antara Allah dan dunia ciptaan. Selain itu, fakta bahwa penciptaan merupakan bentuk Kasih Allah yang tak terbatas juga mewarnai percakapan kontemporer tentang penciptaan. Bersamaan dengan itu, Allah dikenal sebagai Allah yang subur dan komunikatif. Berseberangan dengan paham Allah yang subur, penulis mengusulkan metafora Allah yang mandul dalam penciptaan dunia. Kompleksitas chaosmos akan memberikan sudut pandang berbeda terkait metafora ini. Perlu diingat, Rahim mandul Allah merupakan sebuah metafora yang menggambarkan keadaan bumi pra-penciptaan.

\section{Kompleksitas Chaosmic sebagai Wajah Kemandulan Allah}

Salah satu isu menarik dalam teologi penciptaan ialah kemunculan dunia yang ditandai dengan Chaos. Istilah Chaos dapat berarti ruang yang kuat, tempat inkubasi atau sumber dari kemunculan hal-hal baru. Menurut Susan Willhauck, chaos dalam Alkitab ditafsirkan sebagai musuh Allah, hukuman, kehancuran, dan kejahatan. ${ }^{35}$ Namun, menurut beberapa Teolog, seperti John Levenson, ${ }^{36}$ Michael Austin, ${ }^{37}$ Janet Warren, ${ }^{38}$ Richard Averbeck ${ }^{39}$,

34 Lih. Choan-Seng Song, Theology from the Womb of Asia (NY: Orbis Books, 1985), 115.

${ }^{35}$ Susan Willhauck, "God's Stuff: The Constructive Powers of Chaos for Teaching Religion: Teaching Metaphor," Teaching Theology and Religion 13, no. 1 (2010): 64.

${ }^{36}$ Lih. Erich Michael Vail, Creation and Chaos Talk: Charting a Way Forward (Eugene, Ore.: Pickwick Publications, 2012), 83-85, https://www.perlego.com/book/879403/creation-and-chaos-talk-charting-away-forward-pdf?quer.

37 Michael Ridgwell Austin, Explorations in Art, Theology and Imagination (Routledge, 2016), 117.

38 E Janet Warren, Cleansing the Cosmos : A Biblical Model for Conceptualizing and Counteracting Evil (Eugene, Oregon: Pickwick Publications, 2012), 58.

${ }^{39}$ Richard Averbeck, "Ancient Near Eastern Mythography as It Relates to Historiography in the Hebrew Bible: Genesis 3 and the Cosmic Battle," in The Future of BIblical Archaeology: Reassessing Methodologies and Assumptions: The Proceedings of a Symposium, August 12-14, 2001 at Trinity International University, ed. James Karl Hoffmeier and Alan Ralph) Millard (Grand Rapids, Mich.: W.B. Eerdmans Pub., 2004), 347-348,351. 


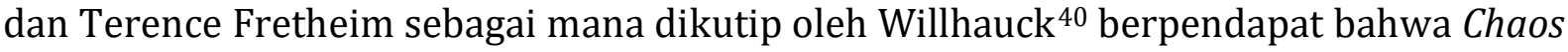
dan Cosmos tidak dapat dipandang demikian, karena chaos merupakan metafora. Simbol chaos termasuk the deep dan embrio kosmik, matriks dari semua hal yang akan datang. ${ }^{41}$

Percakapan tentang chaos selalu diperhadapkan dengan doktrin creatio ex nihilo. Kitab Kejadian mencatat tohu wa-bohu (Kej.1:2) sebagai keadaan pra-penciptaan, yang kemudian didoktrinisasi sebagai penciptaan dari ketiadaan/kekosongan (Latin: creatio ex nihilo). Eric Michael Vail mengklaim bahwa Kejadian 1:1-2:3 hanya menampilkan keadaan tohu wa-bohu, lautan, dan roh Allah yang melayang-layang. Tidak ada hal lain, termasuk chaos, kejahatan, dan materi lainnya. ${ }^{42} \mathrm{Hal}$ serupa juga ditekankan oleh Eben Nuban Timo, bahwa tohu wa-bohu yang dihubungkan dengan Kejadian 2:4b-5 tidak menunjukkan chaos. Sebaliknya, ia menunjukkan keadaan bumi yang unproductive, belum menghasilkan apa-apa (tohu), dan yang uninhabited atau belum didiami (bohu). Tohu wabohu merujuk pada keadaan bumi yang masih kosong-melompong. Timo berkata, "Bumi pada waktu diciptakan Allah masih seperti padang gurun yang kosong karena tandus dan mandul." 43

Terlepas dari problematika dan perdebatan terkait doktrin creatio ex nihilo, penulis membayangkan keadaan bumi pra-penciptaan yang ditandai dengan chaos sebagai wajah kemandulan Allah. Rahim Allah yang merengkuh kekosongan-kekacauan dan menciptakan dunia adalah rahim yang mandul. Pernyataan ini menjadi pematik bagi kita untuk mendiskusikan realitas chaotic sebagai wajah kemandulan Allah.

Sama halnya dengan kemandulan, Chaos juga sering dikaitkan dengan kejahatan dan keburukan. Kondisi ini disebut chaotic. Menanggapi hal ini, Marjorie Boyle berpendapat bahwa gagasan tentang chaos dalam Alkitab sering dikaitkan dengan isu moralitas, seperti kejahatan, pengalaman, dan kehidupan manusia yang kacau. Namun, realitas chaotic tersebut bukanlah memori primitif pada kehidupan masa lampau, melainkan cerminan kehidupan kacau (chaotic) dewasa ini. Ia berkata, "The Bible invites movement 'out of a world of chaos'." 44

Paradigma chaotic tersebut diadopsi dari kosmogoni Babel, yakni Enuma eliš. Catherine Keller menjelaskan, Enuma eliš merupakan mitologi penciptaan Babel, dengan Tiamat sebagai tokoh utama. ${ }^{45}$ Keller, berdasarkan tafsir tehomisnya, berpendapat

40 Willhauck, “God's Stuff: The Constructive Powers of Chaos for Teaching Religion: Teaching Metaphor," 64.

41 Ibid.

42 Eric Michael Vail, "Using 'Chaos' in Articulating the Relationship of God and Creation in God's Creative Activity” (Marquette University, 2009), 128.

43 Ebenhaizer. I Nuban Timo, Allah Menahan Diri, Tetapi Pantang Berdiam Diri: Suatu Upaya Berdogmatika Kontekstual Di Indonesia, I. (Jakarta: BPK Gunung Mulia, 2015), 202.

44 Marjorie O’Rourke Boyle, “The Beginning of Chaos for Genesis," Journal for the Study of the Old Testament 43, no. 4 (2019): 589.

45 Keller, The Face of the Deep: A Theology of Becoming, 28. 
bahwa wajah pertama dunia adalah wajah seorang perempuan, yaitu satu dewi Babel, yakni Tiamat (Salt water, Primal Chaos) yang jahat. ${ }^{46}$ Berdasarkan mitos, Tiamat adalah ibu yang jahat, musuh dari semua kehidupan. Wajah dewi tersebut dilucuti dari intertekstualitas misterius, ${ }^{47}$ yang merepresentasi chaos atau disorder sebagai kejahatan. Bagi Keller,

There can be no rebirth from (or of) her Godforsaken womb: "The Old Testament and the present text know absolutely nothing of any such 'Die and become' with reference to tehom. Nor do they know anything of a motherhood of tehom. They give it no such chance."48

Bayang-bayang feminin yang membingungkan terhadap tehom telah meliputi berbagai perdebatan filosofis tentang penciptaan dunia. Menurut Keller, Tehom, di satu sisi merupakan kata singular feminin dalam gender, namun di sisi lain tehom (Kej. 1:2) juga adalah sebuah misteri. ${ }^{49}$ Teolog Kristen memiliki tugas untuk merespons Tehom berdasarkan sudut pandang mereka tentang penciptaan dunia. Keller menambahkan, ortodoksi yang meninggikan "Bapa" sebagai satu-satunya sebutan bagi Sang Pencipta menimbulkan pertanyaan tentang bagaimana kapasitas seorang perempuan dalam proses penciptaan? "So tehom had first and always again to be sterilized."50 Meminjam pandangan dari Ghandian Satyagraha, Keller merumuskan preposisi etika tehomis, sebagai berikut: "To Love is the bear with the chaos. Not to like it or to foster it but to recognize there the unformed future."51

Kompleksitas pemahaman mengenai chaos, Enuma eliš, Tiamat, dan tehomology dalam pemikiran Keller merupakan gambaran dari konflik-konflik kuno tentang proses penciptaan dan respons pemikiran terhadap isu gender. Hal ini akan sangat berdampak pada metafora rahim mandul Allah. Dengan kata lain, anggapan bahwa chaos adalah kejahatan akan mempengaruhi pemahaman manusia tentang kemandulan sebagai keburukan dan harus ditolak.

Namun, tafsir dekonstruktif Keller terhadap doktrin creatio ex nihilo membuktikan bahwa teologi Kristen yang mengaitkan chaos dengan perempuan (Tiamat, dewi jahat dalam mitologi Babel) adalah sesuatu yang perlu dibatasi. Keller menjelaskan, chaos bukanlah suatu kejahatan atau bukan tidak ada, melainkan potensi utama dari theology of becoming, ${ }^{52}$ yang merefleksikan kebaikan dan kejahatan (order and dis/order) secara

46 Ibid.

47 Ibid., 18.

48 Ibid., 18-19.

49 Ibid., 28; Catherine Keller, On the Mystery: Discerning Divinity in Process (Minneapolis, MN: Fortress Press, 2008), 61.

${ }^{50}$ Keller, The Face of the Deep: A Theology of Becoming, 19.

51 Ibid., 29.

52 Theology of Becoming juga sarat makna akan gelombang tehomis yang sangat aktif sebagai sumber dosa. Untuk itu, membaca tehom sebagai spontanitas chaosmic dari semua yang diciptakan, dapat 
bersamaan. ${ }^{53}$ Keller menambahkan, Kesenjangan antara nihil dan tehom memberi kemungkinan yang pasti, yakni peluang untuk kreativitas yang tidak membingungkan dan tidak subjektif. ${ }^{4}$ Sehingga, ia mengusulkan Hubungan saling ketergantungan antara Allah dan dunia, dengan begitu, Allah dan ciptaan sama-sama berperan dalam karya penciptaan. 55

Hal ini menunjukkan bahwa the infinite of a chaosmic hermeneutic signal bukan hanya sebuah makna melainkan makna penuh makna, yang dihasilkan oleh penolakan dan batas yang jelas. ${ }^{56}$ Oleh sebab itu, chaos bukan sekadar disorder melainkan suatu kondisi puncak, awal dari kemunculan dunia. Transfigurasi indeterminasi dari chaos menyebabkan icon chaos menjadi kreatif. Artinya, sebagaimana proses penciptaan dan Allah bertindak sebagai Pencipta, Allah yang adalah dunia itu sendiri merengkuh chaos dan mendatangkan order (dunia). Dengan demikian, Allah merupakan penyebab segala sesuatu (Self-caused) dari kacau menjadi ada.

Gagasan tentang chaos tidak menggambarkan dualisme penciptaan, yaitu ketidakberaturan dan keteraturan, semua atau tidak sama sekali, tetapi keduanya hidup berdampingan dalam interaksi yang dinamis. Interaksi ini menciptakan ketegangan dan energi. ${ }^{57}$ Gagasan ini sejalan dengan istilah chaordic. ${ }^{58}$ Secara abstrak Keller berusaha untuk menggambarkan hubungan antara chaos dan order, dalam kaitannya dengan tehom dan chaosmic (chaos dan cosmic). Bagi Keller, chaos yang selalu hilang dalam terjemahan Alkitab, telah mulai mengubah doktrin berirama nihil aliquid, dan tohu wa-bohu dapat dibaca dengan fluktuasi ganda, bahwa penciptaan berlangsung dari keadaan non-material menjadi ada. Dengan demikian, chaos menjadi tempat untuk konstruksi order secara berbeda. 59

Kejadian 1:2 memberi perhatian pada penciptaan Allah melalui Firman dan Roh Allah yang melayang-layang di atas permukaan bumi yang unproductive dan uninhabited. Menurut Eben Timo, ini harus dilihat sebagai tindak kreatif Allah yang akan segera

kemudian menghasilkan pemahaman yang mengarah pada aktualisasi kebaikan dan kejahatan. Lih. Ibid., 80 .

53 Willhauck, "God's Stuff: The Constructive Powers of Chaos for Teaching Religion: Teaching Metaphor," 63-64; Keller, The Face of the Deep: A Theology of Becoming, 81.

${ }^{54}$ Keller, The Face of the Deep: A Theology of Becoming, 6.

55 Ibid., 10.

56 Ibid., 146. Metaphor," 66.

57 Willhauck, “God's Stuff: The Constructive Powers of Chaos for Teaching Religion: Teaching

58 Secara etimologi Chaordic merupakan singkatan dari kata chaos (ketidakberaturan/kekacauan) dan order (keteraturan). Chaordic berkaitan erat dengan istilah Self-Organization dalam percakapan modern tentang kemunculan dunia.

${ }^{59}$ Keller, The Face of the Deep: A Theology of Becoming, 186-87. 
menciptakan bumi yang produktif dan habited. ${ }^{60}$ Sebagaimana yang ditulis oleh Catherine Keller, "Being at home as being 'expected': an image redolent of pregnancy, nurturance, hospitality." 61

Keller kemudian menyoroti keterlibatan Elohim ke dalam hubungan teologis dengan materi tohu wa-bohu. Baginya, dalam menghadapi kompleksitas self-organizing dari alam semesta, terdapat suatu sarana kreatif yang memungkinkan Allah berdiam bersama dengan ciptaan. ${ }^{62}$ Baginya, metafora self-organizing merupakan respons dunia, artinya ciptaan merespons daya pikat Pencipta, dan Sang Pencipta menanggapi tindakan ciptaan tersebut. Respons tersebut adalah becoming. Tanpa adanya hubungan timbalbalik semacam ini dalam teks Kejadian, tidak mungkin ada teolog yang serius menanggapi penciptaan sebagai fluktuasi tak berujung, an order emerges. ${ }^{63}$ Keller menawarkan kasih sebagai pengikat relasi timbal-balik antara Allah dan ciptaan. Tidak seperti cosmic eros, dengan watak mitologis bisexual, hybrid, dan playful atmosphere, agape Kristen memancarkan suatu antropomorfisme orangtua, sebuah abdikasi unilateral yang jauh dari tohu wa-bohu. ${ }^{64}$

Meminjam pemikiran Ivone Gebara dan Sallie McFague, Catherine Keller juga mengusulkan dunia sebagai tubuh Allah. Menurutnya, di dalam hubungan antara tubuh Allah dan chaos terdapat relasi kasih-karunia yang memungkinkan ciptaan berada di dalam tubuh Allah, dan Allah mendiami dunia bersama seluruh ciptaan. ${ }^{65}$ Bagi Keller, dunia bukan sekadar serangkaian peristiwa yang terikat pada waktu. Sebaliknya, ciptaan muncul dari suatu ketidakjelasan atau kekacauan. Matriks kacau ini disebut sebagai "rahim atau tempat", yang berada di dalam Allah. ${ }^{66}$ Menurutnya, meskipun Allah adalah transenden, namun rahim yang bersifat tak terbatas layak untuk disematkan pada tubuh yang tak terbatas. ${ }^{67}$ Phillip Clayton menyimpulkan, matriks tersebut adalah tempat pertama atau kapasitas Rahim. Dengan demikian, konsep penciptaan pasif (nihilo) menjadi ruang yang aktif, tanpa batas di dalam Allah, sebagai tempat penciptaan berlangsung. 68

Kompleksitas chaosmos dalam pemikiran Keller menuntun kita pada sebuah kesimpulan bahwa Allah merupakan penyebab segala sesuatu, atau dengan kata lain,

60 Nuban Timo, Allah Menahan Diri, Tetapi Pantang Berdiam Diri: Suatu Upaya Berdogmatika Kontekstual Di Indonesia, 202-203.

${ }^{61}$ Keller, The Face of the Deep: A Theology of Becoming, 191.

62 Ibid., 194.

63 Ibid., 198.

64 Ibid., 199.

65 Ibid., 21.

66 Thomas Jay Oord, Theologies of Creation: Creatio Ex Nihilo and Its New Rivals, Creatio Ex Nihilo and Its New Rivals (New York: Routledge, 2015), 20.

${ }^{67}$ Keller, The Face of the Deep: A Theology of Becoming, 225.

68 Mary-Jane Rubenstein, "Myth and Modern Physics: On the Power of Nothing," in Theologies of Creation: Creatio Ex Nihilo and Its New Rivals, ed. Thomas Jay Oord (New York: Routledge, 2015), 28-30. 
Allah adalah dunia itu sendiri. Dunia adalah rahim Allah dan chaos adalah gambaran realitas kemandulan dewasa ini. Selain itu, dekonstruksi Keller menghasilkan struktur penciptaan yang beroposisi dengan matriks chaosmic yang dianggap jahat. Chaos bukan suatu kejahatan, melainkan potensi utama dari kemunculan dunia. Allah dalam kekekalan-Nya, merengkuh kekacauan dan menciptakan order dalam kerahiman-Nya. Ini berarti, kemandulan bukan suatu kejahatan melainkan realitas chaotic yang berdampingan dengan order.

Dengan demikian, dunia sebagai rahim mandul Allah adalah kumpulan entitas dalam kebersamaan chaotic. Baik dan jahat, hidup dan mati, manis dan pahit, suka dan duka, manusia dan non-manusia, serta subur dan mandul, berdampingan di dalam satu kesatuan. Rahim mandul Allah adalah rumah (home and house) bersama bagi kesetaraan laki-laki dan perempuan dan perempuan dengan berbagai pengalaman tubuh dalam kebersamaan Chaotic. Chaotic adalah sebuah fluktuasi positif dari penciptaan dunia dan vitalitas semesta kepada Allah. Karena itu, kemandulan tidak harus dimengerti sebagai aib, stigma, dan penolakan. Pemahaman semacam ini mendorong kita untuk menerima perempuan-perempuan mandul sebagai bagian dari realitas hidup manusia.

\section{Perempuan mandul dalam Rahim mandul Allah}

Metafora rahim mandul Allah telah menawarkan persepktif "kebersamaan chaotic", suatu konsep yang mengagas kesetaraan sebagai hak mutlak bagi tiap individu yang berdiam di dalam rahim Allah dan menjalin relasi kasih dengan sang Pencipta, juga sesama. Gagasan tersebut berarti baik perempuan mandul, perempuan yang enggan untuk mengandung, maupun perempuan tak ber-anak pun merupakan bagian dari realitas chaotic tersebut. Semua perempuan adalah ciptaan Allah, dan karenanya memiliki hak yang sama, yakni bebas menentukan kehidupan seperti apa yang harus ia jalani.

Sayangnya, inferioritas perempuan mandul dan perempuan-perempuan tidak berkemauan untuk bereproduksi menghadirkan stigma, yang penulis sebut sebagai disabilitas budaya, yakni budaya normal yang menyoroti peran keibuan dan bersalin adalah universal bagi setiap perempuan. Kegagalan untuk bereproduksi sering dianggap menyimpang norma sosial. ${ }^{69}$ Artinya, kemandulan dipahami sebagai penyimpangan, penurunan nilai sosial, hal yang memalukan, dan mengarah pada stigma dalam banyak kelompok sosial dan agama, ${ }^{70}$ termasuk dalam lingkup keluarga.

Normalisasi dimaksud telah mendiskriminasi dan mengintervensi pengalaman tubuh perempuan yang beragam. Penulis sering mendengar kutipan yang menyatakan bahwa "kodrat perempuan hanya tiga, yakni menstruasi, mengandung, dan menyusui". Pernyataan tersebut sering digunakan untuk melawan isu gender terhadap peran

69 Powell, “The Infertile Womb of God: Ableism in Feminist Doctrine of God," 121.

70 Ibid., 122. 
perempuan dalam rumah tangga, serta membantah berbagai stigma sosial terhadap perempuan. Penyataan ini baik sebab menonjolkan pembedaan natur laki-laki dan perempuan. Akan tetapi, tidak pro terhadap pengalaman perempuan mandul dan perempuan yang enggan untuk memiliki anak. ${ }^{71}$

Selain itu, peran manusia sebagai mandataris Allah, yakni "beranakcuculah dan bertambah banyak; penuhilah bumi dan taklukkanlah itu" (Kej. 1:28), cukup problematis, sebab pasangan yang tidak memiliki anak akan dianggap tidak menjalankan perintah Allah. Mengutip Candida Moss dan Joel Baden, Janice Pearl Ewurama De-Whyte mengatakan bahwa frasa tersebut bukan titah Allah, melainkan berkat. Dengan demikian, kemandulan bukanlah stigma yang harus dimanipulasi sebagai penolakan dan hukuman. ${ }^{72}$

Stigma kemandulan yang berkembang dalam masyarakat, menyebabkan perempuan mandul didiskriminasi dan dimarginalisasi. Mereka kerap mendapat gunjingan "tidak berharga dan bermanfaat sebagai perempuan" dan "bukan perempuan seutuhnya". Gunjingan tersebut hadir tanpa peduli pada keberagaman pengalaman tubuh perempun. Autumn Reinhardt-Simpson berpendapat bahwa dunia, masyarakat, bidangbidang pekerjaan, dan teologi Kristen sering kali gagal memperhitungkan keberagaman hidup perempuan. ${ }^{73}$ Pembelaan teologis terhadap hak-hak reproduksi perempuan cenderung berfokus pada statistik, abstraksi, dan permintaan maaf dari pelaku tindakan diskriminatif kepada korban, seolah-olah perempuan seharusnya dibiarkan membimbing kehidupan reproduktif mereka demi kebutuhan orang lain. ${ }^{74}$ Secara teologis, pengalaman perempuan telah ditulis sebagai bagian dari kehidupan spiritual yang "normal" dan "standar", yakni berdasarkan spiritualitas laki-laki.

Hal ini menyebabkan tubuh-tubuh perempuan mengalami berbagai bentuk diskriminasi di bawah kekuasaan laki-laki selama berabad-abad. Menurut Megan Clay, sistem patriarki yang mendominasi telah merendahkan posisi perempuan, sekaligus menempatkan perempuan dan alam semesta pada posisi negatif. Hal ini menimbulkan trauma pada tubuh perempuan di sepanjang generasi dan sangat mempengaruhi perkembangan potensi seorang perempuan. ${ }^{75}$ Clay menambahkan, tubuh yang menyimpan begitu banyak trauma dan pengalaman emosional dapat terbaring secara menyedihkan dalam jaringan tubuh perempuan selama berabad-abad.

Pengalaman perempuan mandul dapat menjadi salah satu contoh tentang inferioritas seorang perempuan mandul dalam komunitas masyarakat. Ketidakberdayaan

\footnotetext{
Childfree.

72 De-Whyte, Wom(b)an: A Cultural-Narrative Reading of the Hebrew Bible Barrenness Narratives, 7.

73 Autumn Reinhardt-Simpson, "Theology Outside the Clinic," CrossCurrents 66, no. 4 (2016): 502.

74 Ibid.

75 Clay, "Abundant Body Narratives: Re-Visioning the Theological Embodiment of Women through Feminist Theology and Art as a Way of Flourishing," 249.
}

${ }^{71}$ Istilah yang digunakan untuk perempuan yang memutuskan untuk tidak memiliki anak adalah 
perempuan mandul untuk merespons realitas di sekitarnya turut mempengaruhi ruang gerak dan statusnya di dalam komunitas sosialnya (khususnya, di dalam lingkungan keluarga).

Mengutip Tess Tessier, yang berbicara tentang suara-suara primitif leluhur dan irama alam semesta yang berpotensi untuk melibatkan perkembangan potensi pada perempuan, Clay berpendapat bahwa kualitas visual dapat menciptakan gambaran kosmik yang mendorong seorang perempuan untuk mendengarkan tubuh mereka, dan sekaligus membuka ruang bagi setiap perempuan untuk menyelam ke kedalaman diri, yang belum pernah dijelajahi dan membuat hubungan teologis dengan diri mereka sendiri. ${ }^{76}$

Persoalan demikian akan lebih efektif dipecahkan secara teologis melalui metafora rahim mandul Allah. Melalui Penciptaan, kita memahami bahwa Allah mengingat semua ciptaan. Dunia sebagai rahim mandul Allah menolong kita untuk memahami bahwa kita hidup dalam keberagaman dan kebersamaan chaotic. Dunia adalah rumah bagi keberagamaan dan kesetaraan. Mengutip Sallie McFague "A living body in which we all participate, continually merging and emerging in rhythmic cycles."77 Semua ciptaan di undang untuk berpartisipasi dalam keberlanjutan karya penciptaan Allah di dunia, yakni dengan menyatakan kasih Allah atas semesta.

Menerima perempuan mandul sebagai bagian dari realitas chaotic adalah usaha untuk mencapai kesetaraan antar perempuan dan bentuk apresiasi pada tubuh perempuan. Bagaimana pun, setiap perempuan berhak untuk menentukan kehidupan seperti apa yang harus ia jalani, ia juga berhak untuk memilih akan mengandung atau tidak. Di sisi lain, seorang perempuan juga tidak bisa menolak tubuhnya yang mandul, sebab kemandulan bisa terjadi begitu saja. Allah yang mandul menerima semua kita tinggal di dalam-Nya, sehingga kita juga seharusnya bisa menerima kemandulan sebagai hal yang positif. Seorang mandul bukan penjahat, bukan kriminalis, ataupun tidak berharga. Ia adalah bagian dari kita. Oleh sebab itu, menerima perempuan mandul dan keputusan seorang perempuan untuk tidak memiliki anak adalah wujud dari penyataan Kasih Allah dalam keseharian kita.

\section{Kesimpulan}

Percakapan teologis mengenai proses penciptaan dunia sangat beragam. Salah satu isu feminis yang dipercakapkan terkait penciptaan ialah teologi rahim. Allah digambarkan sebagai Pencipta yang menciptakan segala sesuatu dalam rahim-Nya. Model Panenteisme mendukung pernyataan ini, bahwa segala sesuatu berada di dalam Allah dan Allah berada di dalam segala sesuatu (Allah berdiam bersama ciptaan). Relasi intim antara Allah dan

\footnotetext{
${ }^{76}$ Ibid., 254-55.

77 McFague, The Body of God: An Ecological Theology, Kindle, Loc. 501-502.
} 
ciptaan tercermin melalui pengalaman ibu mengandung. Allah adalah si Ibu dan janin dalam kandungan adalah kehidupan ciptaan, keduanya saling terhubung melalui tali pusat. Teologi yang demikian digambarkan mengikuti model-model ideal masyarakat yang menghendaki perempuan wajib mengandung, melahirkan, dan menyusui. Keberhargaan perempuan diukur berdasarkan kemampuannya untuk bereproduksi. Hal ini menghadirkan stigma dan diskriminasi terhadap tubuh perempuan mandul dan perempuan yang enggan memiliki anak.

Merespon hal itu, penulis mengusulkan metafora rahim mandul Allah. Harus ditekankan bahwa rahim mandul Allah merupakan sebuah metafora yang memberi penekanan teologis pada keadaan pra-penciptaan yang ditandai dengan chaos. Penulis melihat dunia adalah rahim Allah dan chaotic adalah realitas kemandulan dewasa ini.

Dinamika chaotic penciptaan dunia tawaran Catherine Keller memberi ruang bagi penulis untuk menyatakan gagasan bahwa kemandulan merupakan kebaikan yang harus diterima. Sehingga, perempuan-perempuan mandul memiliki hak dan tempat yang sama dalam semesta, juga dalam komunitas sosialnya. Dunia sebagai rahim mandul Allah adalah rumah bersama bagi kesetaraan, tempat setiap perempuan bebas untuk menentukan kehidupan yang ia jalani, serta tempat saling menghargai dan melindungi kebebasan reproduksi tiap perempuan. Akhirnya, Penulis berharap tulisan ini dapat memberi pencerahan bagi para pembaca yang masih menganggap kemandulan sebagai aib, hukuman Allah, kejahatan, dan keburukan.

\section{Referensi}

Atmanspacher, Harald, and Hartmut von Sass. "The Many Faces of Panentheism: An Editorial Introduction." Zygon (2017): 1029-1043.

Austin, Michael Ridgwell. Explorations in Art, Theology and Imagination. Routledge, 2016.

Averbeck, Richard. "Ancient Near Eastern Mythography as It Relates to Historiography in the Hebrew Bible: Genesis 3 and the Cosmic Battle." In The Future of BIblical Archaeology : Reassessing Methodologies and Assumptions : The Proceedings of a Symposium, August 12-14, 2001 at Trinity International University, edited by James Karl Hoffmeier and Alan Ralph) Millard. Grand Rapids, Mich.: W.B. Eerdmans Pub., 2004.

Bauman, Christy Angelle. Theology of The Womb: Knowing God through the Body of a Woman. Eugene: Wipf and Stock, 2019.

Bilimoria, Purushottama, and Ellen Stansell. "Suturing the Body Corporate (Divine and Human) in the Brahmanic Traditions." In Sophia, 237-259, 2010.

Boyle, Marjorie O'Rourke. "The Beginning of Chaos for Genesis." Journal for the Study of the Old Testament 43, no. 4 (2019): 588-606.

Clay, Megan. “Abundant Body Narratives: Re-Visioning the Theological Embodiment of 
Women through Feminist Theology and Art as a Way of Flourishing." Feminist Theology 25, no. 3 (2017): 248-256.

Clayton, Philip. “Panentheisms East and West.” Sophia 49, no. 2 (2010): 183-191.

De-Whyte, Janice Pearl Ewurama. Wom(b)an: A Cultural-Narrative Reading of the Hebrew Bible Barrenness Narratives. Leiden: Brill, 2018.

Göcke, Benedikt Paul. "Panentheism and Classical Theism.” Sophia 52, no. 1 (2013): 6175.

Gregersen, Neils Henrik. "Three Varieties of Panentheism." In In Whom We Live and Move and Have Our Being: Panentheistic Reflections on God's Presence in a Scientific World, edited by Philip Clayton and Arthur Robert Peacocke. Grand Rapids, MI: William B. Eerdmans Pub., 2004.

Griffin, David. "Panentheism: A Postmodern Revelation.” In In Whom We Live and Move and Have Our Being: Panentheistic Reflections on God's Presence in a Scientific World, edited by Philip Clayton and Arthur Robert Peacocke. Grand Rapids, MI: William B. Eerdmans Pub., 2004.

Keller, Catherine. On the Mystery: Discerning Divinity in Process. Minneapolis, MN: Fortress Press, 2008.

-_- The Face of the Deep: A Theology of Becoming. Florence: Routledge, 2003.

McFague, Sallie. The Body of God: An Ecological Theology. Minneapolis: Fortress Press, 1993.

Nuban Timo, Ebenhaizer. I. Allah Menahan Diri, Tetapi Pantang Berdiam Diri: Suatu Upaya Berdogmatika Kontekstual Di Indonesia. I. Jakarta: BPK Gunung Mulia, 2015.

Nugrahani, Farida. Metode Penelitian Kualitatif. Solo: Cakra Books, 2014.

Oord, Thomas Jay. Theologies of Creation: Creatio Ex Nihilo and Its New Rivals. Creatio Ex Nihilo and Its New Rivals. New York: Routledge, 2015.

Pattinama, Yenny Anita, and Febriaman Lalaziduhu Harefa. "Spiritualitas Hana Menurut 1 Samuel 1: 1-28 Dan Implementasinya Bagi Wanita." SCRIPTA: Jurnal Teologi dan Pelayanan Kontekstual 10, no. 2 (2020): 1-20.

Powell, Lisa. "The Infertile Womb of God: Ableism in Feminist Doctrine of God." CrossCurrents 65, no. 1 (2015): 116-138.

Reinhardt-Simpson, Autumn. "Theology Outside the Clinic." CrossCurrents 66, no. 4 (2016): 501-519.

Remennick, Larissa. "Childless in the Land of Imperative Motherhood: Stigma and Coping Among Infertile Israeli Women." Sex roles 43, no. 11 (2000): 821-841.

Rubenstein, Mary-Jane. "Myth and Modern Physics: On the Power of Nothing." In Theologies of Creation: Creatio Ex Nihilo and Its New Rivals, edited by Thomas Jay Oord. New York: Routledge, 2015. 
Schaab, Gloria L. "Midwifery as a Model for Ecological Ethics: Expanding Arthur Peacocke's Models of 'Man-in-Creation.'” Zygon 42, no. 2 (2007): 487-498.

Schones, David A. "Infertility in 1 Samuel 1: Toward a Hermeneutic of Reproduction." Southern Methodist University, 2019.

Siregar, Christian. "Menyoal Jenis Kelamin Allah Dalam Perspektif Teologi Feminis: Menuju Teologi Yang Lebih Berkeadilan Terhadap Perempuan." Humaniora (2015): 433-443.

Song, Choan-Seng. Theology from the Womb of Asia. NY: Orbis Books, 1985.

Susanta, Yohanes Krismantyo. “Teologi Biblika Kontekstual Di Seputar Persoalan Perempuan, Keturunan, Dan Kemandulan." Religious: Jurnal Studi Agama-Agama dan Lintas Budaya 4, no. 3 (April 4, 2020): 177-190. https://journal.uinsgd.ac.id/index.php/Religious/article/view/8079.

Vail, Eric Michael. "Using 'Chaos' in Articulating the Relationship of God and Creation in God's Creative Activity." Marquette University, 2009.

Vail, Erich Michael. Creation and Chaos Talk: Charting a Way Forward. Eugene, Ore.: Pickwick Publications, 2012. https://www.perlego.com/book/879403/creationand-chaos-talk-charting-a-way-forward-pdf?quer.

Warren, E Janet. Cleansing the Cosmos : A Biblical Model for Conceptualizing and Counteracting Evil. Eugene, Oregon: Pickwick Publications, 2012.

Willhauck, Susan. “God's Stuff: The Constructive Powers of Chaos for Teaching Religion: Teaching Metaphor." Teaching Theology and Religion 13, no. 1 (2010): 64-70.

Zaluchu, Sonny Eli. "Strategi Penelitian Kualitatif Dan Kuantitatif Di Dalam Penelitian Agama." Evangelikal: Jurnal Teologi Injili dan Pembinaan Warga Jemaat 4, no. 1 (2020): 28-38. 